\section{From détente to development}

Eric Burhop reports on the discussion

between scientists at the 27th Pugwash Conference

A T'TENDANCE at the 27th Pugwash Conference, held in Munich on 24-29 August, was as always on an individual basis, facilitating the frank and uninhibited exchanges between scientists of very different backgrounds that has always been a feature of Pugwash. Two hundred and sixty participants from 54 countries met to discuss problems of universal concern: détente, human rights, energy and development. About 50 of them came from countries of the Third World. Those not attending on an individual basis included 18 observers representing governmental international organisations.

In his address to the opening session, Herr Matthöfer, Minister of Research and Technology of the Federal German Republic, remarked "Today Pugwash is a very familiar name, indeed a symbol of the responsible active efforts of scientists from all over the world to help solve the major world-wide tasks of humanity across political and ideological barriers".

For those who may not be so familiar with the history, Pugwash is the name of a small Nova Scotian village, birthplace of the Cleveland, Ohio, industrial magnate, Cyrus Eaton, who financed the first of these conferences held there in July 1957. The call for the holding of such a conference came in a remarkable statement drafted by Bertrand Russell in his incomparably clear and compelling language and beginning: "In the tragic situation which confronts humanity, we feel that scientists should assemble in conference to discuss the perils that have arisen as

Eric Burhop is Professor of Physics at University College, London, and President of the World Federation of Scientific Workers.

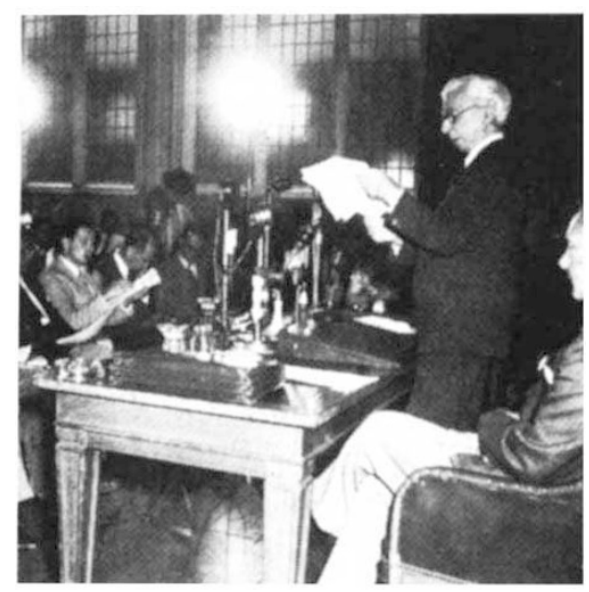

Russell at the 1955 press conference a result of the development of weapons of mass destruction . . ." *The statement goes on to spell out to the world the grave and immediate dangers to the whole of humanity implicit in the development of the hydrogen bomb. It was signed by Einstein only two days before his death in May 1955 and by nine other eminent scientists from six countries. The Russell-Einstein Manifesto, as it has come to be known, was presented to the world at a press conference presided over by Joseph Rotblat and held in Caxton Hall, London, in July 1955.

\section{Two roles}

There have always been two conceptions of the aims of the Pugwash Conferences. The Russell-Einstein Manifesto looked to them to rouse public opinion to the dangers of the development of nuclear weapons by issuing statements which, coming from scientists of such eminence and integrity, could be ignored neither by peoples nor by governments. The other concept of the role of Pugwash as providing facilities for private discussions between the very experts from NATO and Warsaw Pact countries who were advising their governments on problems of weapons development and disarmament, was especially associated with the thinking of Leo Szilard.

Both Pugwash roles have had an important effect on relations between the two power blocs in the past. The mutual understanding of each other's thinking has made remote the possibility of stumbling into nuclear war by accident, through, for example, wrong interpretation of observations on a radar screen. Pugwash Conferences have been credited with playing a significant role in achieving the Partial Test Ban and Non-Proliferation Treaties and in the development of the theory of deterrence with its strange array of concepts such as first and second strike capability, mutually assured destruction and all the rest.

The general conferences are held

*It is not widely known that originally Russell was himself sceptical about calling a conference. He envisaged simply the issuing of a statement. The proposal to add the call to scientists to meet in con ference was made by Frédéric Joliot-Curie on behalf of the World Federation of Scientific Workers, of which he was President, in a letter to Russell in January 1955. The writer acted as go-between in the negotiations between Russell and Joliot-Curie. every year, the participants from each country or region being selected by local Pugwash groups. Every fifth year the whole Pugwash community, made up of every participant in previous Pugwash meetings, is eligible to attend. This quinquennial conference elects the principal officers and council of approximately 25 persons that will direct the work for the following five years, assesses the work of the previous quinquennium and plans the future programme. The Munich Conference was a quinquennial one, indeed the largest yet held.

Customarily the conferences work mainly through working groups which deal with specific topics, preparing reports for plenary sessions in the concluding stages of the conference. At the Munjich Conference there were eight such groups dealing with nuclear arms control and disarmament; arms control and disarmament in the nonnuclear realm; coexistence, détente and cooperation between nations and systems; security of developing nations; development problems of the economically poor nations; energy, world resources and population trends; environmental hazards of global concern; science, scientists and society.

The prevailing judgment of the first working group was that the SALT talks are not progressing fast enough to prevent advances in military technology which negate the effect of agreements, based on SALT, already reached. The time for stopping the arms race is running out. There were powerful pleas to examine again basic concepts such as that of deterrence which can at best provide a breathing space. Pugwash should take the lead in pressing for a start on real disarmament and not restrict its approach to arms control measures.

Almost unanimous concern was expressed by several groups about President Carter's decision to go ahead with the development of the neutron bomb. The idea of a weapon specifically designed to kill people while preserving property langely intact has caused a wave of revulsion and it was suggested that Pugwash could recapture some of its old sense of urgency in an appeal to public opinion on issues such as this and on the reported development of a nuclear capability by South Africa.

\section{Public statement}

It is the practice of Pugwash that its conferences, symposia, workshops, etc, issue reports of discussions and recommendations for the benefit of Pugwash members but public statements formulating specific policies on such matters can come only from Council. (See box for the statement issued by Council on these questions, 
reflecting the discussions at the Munich Pugwash Conference.)

The discussions on détente predictably led on to problems of human rights in an atmosphere largely free of acrimonious interchange of charge and countercharge. Appalling departures from acceptable standards are reported from many countries while no country seems faultless. However, the approach to human rights problems should be guided by how to help the victims. They have been used all too often for propaganda purposes or even to attempt to destabilise governments. Discussions on human rights issues tend to be simplistic, the fact that human rights cannot be separated from human responsibilities being forgotten. Nor can the question be adequately discussed in isolation from its social and political framework.

The question of energy supplies practically dominated the discussions on world resources. There was general agreement that ultimately energy needs must be met from solar, wind, geothermal and safe nuclear fusion power but no consensus about how we are to get through the next 40 or 50 years. There was some but not much enthusiasm for the fast breeder solution and a feeling that there was still some time available before committing us to a full programme of fast breeder reactor development. If a determined programme of energy saving were coupled with control of population growth, one could realistically aim for a situation in which, by the year 2020 , the world population would not rise above $6.7 \times 10^{9}$ with an average energy use of $5 \mathrm{kWt}$ (kilowatts-thermal)-8.0 $\mathrm{kWt}$ (rich nations), $3.2 \mathrm{kWt}$ (poor nations)-within a global rate of energy use of only four times that of today. It is believed such a level of demand could be met without introducing breeder technology.

\section{North-South divisions}

The problems of development loomed large in the conference discussions. Indeed, any differences in the conference were far more between North and South than between socialist and non-socialist countries. Many delegates from the Third World do indeed feel that their problems are inadequately dealt with by Pugwash and stress that problems arising from the policies of the industrialised countries relative to the Third World, the role of multinational companies, and also to a lesser extent contradictions between Third World countries themselves may represent the most serious threat to peace. On the other hand, some participants looked back somewhat nostalgically to the early Pugwash Conferences when participants were all more or less expert in some aspect of the field of nuclear weapons and it was possible to issue sharp, incisive statements in this field, carrying great weight. A few felt that there would be a case for two separate types of Pugwash Conferences, one specifically de- voted to disarmament and the other to Third World problems. This would surely be a retrograde step and could only sharpen North-South divisions and the overwhelming view was in favour of continuing as at present.

Pugwash has developed a certain mystique and influence of its own. Some may think it elitist and selfperpetuating; some may chafe at the confidentiality of the discussions, which is an essential feature of the whole Pugwash concept, but it seems that Pugwash is a powerful force for peace and understanding between nations. Thanks to a band of devoted scientists, too numerous to mention but from whom at the present time could be singled out Joseph Rotblat, Bernard Feld, Martin Kaplan, Moishe Markov and Dorothy Hodgkin, the ideas of Russell and Einstein have remained alive and the Pugwash movement has become a living movement with its members showing a genuine sense of loyalty to these ideas and of belonging to the movement.

Of the tasks ahead special emphasis should be placed on the participation of Pugwash in two vital UN meetings: the Special Session of the UN General Assembly on Disarmament in the spring of 1978, and the UN Conference on Science and Technology for Development in the summer of 1979. In both these areas the world community has grievously failed in the past. Here is perhaps an opportunity for a new beginning.

\section{Declaration by the Pugwash Council}

In the light of discussions at the 27th Pugwash Conference on Science and World Affairs, the Council of the Pugwash Movement feels impelled to issue the following declaration:

The world is poised for a new, more intensive and more dangerous round of the arms race. Three features of the world scene account for our sense of heightened urgency and danger:

New weapons of mass destruction. The neutron bomb is proposed for development in the heart of Europe. It is sometimes called a 'clean' or damage-free bomb. On the contrary, both its lethal radiation effects and the short and longterm biological damage it would cause are substantially greater than for existing nuclear weapons of comparable size. There would be strong induced radioactivity from neutron capture in the soil. Because of its relatively small size, it would narrow the distinction between conventional and nuclear weapons and thereby make the use of nuclear weapons more likely.

But the neutron bomb is only one example of new types of weapons now coming into military arsenals: cruise missiles, mobile ballistic missiles, and others. These are of ten provocative and thus destabilising. Their deployment is not verifiable with national means, and thus frustrate efforts at control. And the number of nuclear warheads continues to mount. The deployment of all these new weapons must be stopped.

Proliferation. There was serious concern at the conference over reports of an imminent nuclear-weapons test in South Africa. This concern was not allayed by the assurances by the South African Government that it has no intention do do so. The acquisition of nuclear weapons by South Africa would be a grave peril to the peoples of Southern Africa and the rest of the world. Developments there must be kept under intense continuing surveillance. Any collaboration with South Africa in the nuclear weapon field-whether on the governmental, commercial or scientific level-must stop. The United Nations should be urged to apply effective sanctions should South Africa be proven to be developing nuclear weapons.

But South Africa represents only the most urgent and immediate occasion for concern. At various points around the globe there have been, from time to
time, disturbing reports of states seeking nuclear weapons. We unequivocally condemn moves towards further nuclear weapon proliferation.

The failure of arms control. In spite of endless efforts. progress towards limiting armaments and stopping the arms race has been all but invisible. Everywhere there is a new sense of impasse. And this is particularly ominous in the SALT and MBFR negotiations. There is no military reason for their failure to make progress. No nation's security would be endangered, indeed it would be enhanced, by much lower levels of armaments. The obstacles are political and it requires only political will and political decisions to overcome them.

- We call on the heads of concerned governments and states all over the world, particularly of the USA and USSR, to halt new weapons deployment and reverse the arms race.

- We call on men and women everywhere to redouble their efforts to make their governments understand and act in the face of our common peril.

And we in Pugwash rededicate ourselves to the achievement of a world at peace. 